\title{
The Influence of Financial Literacy, Risk Aversion and Expectations on Retirement Planning and Portfolio Allocation in Malaysia
}

\author{
Nurul Shahnaz Mahdzan, ${ }^{*}$ Amrul Asraf Mohd-Any, and Mun-Kit Chan ${ }^{3}$ \\ ${ }^{1}$ Faculty of Business and Accountancy and Social Security Research Center, University Malaya \\ ${ }^{2}$ Faculty of Business and Accountancy, University of Malaya \\ ${ }^{3}$ Global Markets Department, United Overseas Bank (UOB) Malaysia
}

\begin{abstract}
The two objectives of this paper are to examine the effect of financial literacy, risk aversion and expectations on retirement planning; and, to investigate the effect of these antecedents on the retirement portfolio allocation. Data was collected via a self-administered questionnaire from a sample of 270 working individuals in Kuala Lumpur, Malaysia. Logistic and ordered probit regressions were employed to analyse the first and second objective, respectively. The results from the logistic regression indicate that future expectations significantly influence the probability of planning for retirement. Meanwhile, individuals with higher financial literacy and lower risk aversion are more likely to hold risky assets in their retirement portfolios. Subsequently, two-sample t-test and one-way ANOVA tests were conducted to further examine the differences in financial literacy, risk aversion and expectations, across demographic subgroups. The study contributes to the literature by holistically incorporating the behavioural aspects that affect retirement planning and by exploring an uncharted issue of retirement planning - namely, the retirement portfolio allocation.
\end{abstract}

Keywords: financial literacy; expectations; portfolio allocation; retirement planning; risk aversion.

JEL classification: M1, M5, M13

* Corresponding author's e-mail: n_shahnaz@um.edu.my 


\section{Introduction}

The issues of retirement planning and the adequacy of retirement savings remain at the forefront of academic research and public policy debates across many countries (e.g., Merton 2014; Boisclair et al. 2015). The importance of these issues lies in their relevance to numerous stakeholders, and particularly to the ageing segments of society. Having inadequate retirement savings means that retirees will not be able to sustain their pre-retirement income, may have difficulty maintaining their pre-retirement standard of living, and will need to rely on welfare benefits. While this problem is more of a concern in countries with high rates of population ageing, other countries that are experiencing similar demographic shifts — such as Malaysia - will also need to be prepared to face the consequences of these changes.

Much of the literature has highlighted that there is a growing trend around the world whereby the responsibility for providing sufficient retirement income has shifted from governments and employers to individuals (Lusardi and Mitchell 2007b; Tan and Folk 2011; Merton 2014). In particular, many countries have shifted from traditional defined benefit plans to defined contribution plans. The shift from defined benefit plans to defined contribution plans implies that there is an increasing need for individuals to be adequately knowledgeable of the administration of their own finances, as suggested by researchers who have found a strong link between financial literacy and retirement planning in many parts of the world (Sekita 2011; Boisclair et al. 2015; van Rooij et al. 2012; Brown and Graf 2013).

The literature also suggests that effectiveness in making financial decisions, including planning for retirement, is linked to other behavioral aspects, such as the attitude to risk expectations, and investment horizon (e.g. Junarsin and Tandelilin 2008; Rahardjo 2015). Kasten and Kasten (2011) assert that the emotional capacity to deal with risk and uncertainty is an important criterion in strategic retirement planning, and empirical evidence shows that people who are less risk averse have higher levels of retirement confidence (Joo and Pauwels 2002). Furthermore, empirical evidence shows that risk aversion is strongly related with participation in risky assets, such as mutual funds and stock market investments (e.g., Eeckhoudt et al. 2005; Shum and Faig 2006; Chen et al. 2006; Schooley and Worden 1996).

Future expectations are also important in the process of making financial decisions. Tarrazo and Gutierrez (2000) argue that agents incorporate uncertainty into their decision-making problems based on expectations, and that practical financial planning models - which relate to how financial resources are allocated over time, must be flexible enough and incorporate uncertainty, to be more reflective of the financial planning process. Due to the continuous evolution of the external environment, the role of risk and expectations is crucial in the development of financial plans. This paper is thus built upon the premise that retirement planning involves a complex interaction of behavioral aspects - particularly of risk attitudes and expectations, along with financial literacy- due to the influence of external factors on long-term planning.

Building on the above issues, the two objectives of this paper are: (1) to explore the role of the behavioral factors financial literacy, risk aversion and expectations on retirement planning and, (2) to investigate the effect of those antecedents on the retirement portfolio allocation. This study contributes to the body 
of knowledge on retirement planning through a more holistic incorporation of behavioral aspects postulated to affect retirement planning, and by exploring the rather unchartered issue of retirement planning - that is, retirement portfolio allocation. In this paper, we argue that the issue of a retirement portfolio allocation is imperative, because having retirement plans would naturally lead to the selection of assets to ensure the successful attainment of future financial goals. In addition, this study makes a methodological contribution by employing a nonparametric ordered probit regression method to examine retirement portfolio allocations, given the unique measurement of the proportion of risky assets allocated in the portfolios.

This paper focuses on the question of retirement in the context of Malaysia, as the percentage of its elderly population shows an increasing trend and by 2050, 20 percent- 24 percent of the Malaysian population will be senior citizens (Global Age Watch Index 2015). In addition, reports have indicated that 90 percent of households in rural areas and 86 percent of urban Malaysians have zero savings (Shagar 2016), implying that senior citizens have to continue working past retirement age (Chin 2015). These factors exemplify the seriousness of the retirement issue in Malaysia.

The remainder of this paper proceeds as follows: Section Two presents the relevant literature and hypothesis development, Section Three presents the research methods, Section Four discusses the results, and Section Five concludes the paper.

\section{Literature Review}

\section{Retirement Planning}

The theoretical underpinning of retirement saving is based on the Life-Cycle Hypothesis (LCH) of Modigliani and Brumberg (1954). According to the $\mathrm{LCH}$, individuals will smooth their expenditure patterns over their life-cycle in order to ensure that real consumption trends are kept constant. During times when earning capabilities are high, individuals will save a portion of their income as a reserve to sustain their lives during low earning periods, such as retirement. Since the earning's potential normally increases over the working-life, due to career progression, the ability to save increases over time. However, once retirement age is reached, individuals will have to sustain their lives by using up their accumulated savings.

Based on this traditional life-cycle theory, consumers are rational planners of their own consumption and saving needs over their lifetime (Mitchell and Utkus 2003). However, the assumption of rationality may not be realistic, as researchers have found that many households do not possess the necessary skills and knowledge to estimate their future retirement needs. Furthermore, there is stark evidence that people in developing and developed countries are not prepared to face retirement due to insufficient savings and a lack of planning (e.g., Lusardi 1999, 2003; Ghilarducci et al. 2015; Burnett et al. 2013; Munnell et al. 2011; Poterba 2014; Yuh et al. 1998; Yakoboski and Dickemper 1997; Shagar 2016). 
The fact that the financial industry today offers a more complex selection of financial products poses an even greater challenge to individuals' financial decision making. Consumers who are not well versed in financial knowledge and skills will find it difficult to understand the technicalities of financial products and the risks involved, and may suffer due to inaccurate investment choices. There are various factors contributing to individuals' decisions in regards to building their retirement income portfolio. The theoretical notion underlying the assets' selection and portfolio choices is the modern portfolio theory (Markowitz 1952), which suggests that the portfolio allocation decision is mainly driven by the trade-off between risk and expected returns. For a given level of expected return, the choice of portfolio will be one that minimizer risk exposure, or, for a given level of exposure to risk, the choice of portfolio will be one that offers the highest level of expected return. Thus, individuals' risk aversion plays an important role in the financial asset's selection. However, some studies have raised concern over individuals' ability to make optimal investment decisions that match their risk-return preferences, which would lead to the successful maximization of retirement income (Gallery et al. 2011).

\section{Financial Literacy}

In the past decade, the role of financial literacy in retirement planning has sparked considerable research interest across many countries, in attempts to explain the lack of retirement planning and savings (e.g., Lusardi and Mitchell 2011; Huston 2010; Schmeiser and Seligman 2013; Boisclair et al. 2015; Sekita 2011; van Rooij et al. 2011a, 2011b). The intuition behind the relationship between the two variables is that retirement planning involves a complex process of collecting and processing information (van Rooij et al. 2012). Therefore, individuals need to be suitably knowledgeable in financial matters if they are to have the ability to process numerical and financial information that pertains to their own financial goals.

Among the early works on financial literacy and financial planning was that conducted by Lusardi (1999). Using data from the 1992 US Health and Retirement Survey (HRS), Lusardi showed that individuals aged between 51 and 61 had not yet started to plan, or even think, about retirement. Subsequently, using the 2004 HRS, Lusardi and Mitchell (2007b) showed that those who were more financially knowledgeable were more likely to have thought about retirement. The positive link between financial literacy and retirement planning has also been observed in other countries such as Canada (Boisclair et al. 2015), Japan (Sekita 2011) and the Netherlands (van Rooij et al. 2012). Perplexingly, studies have also found that financial illiteracy is prevalent even in countries that have well developed financial markets (e.g., Germany, the Netherlands, Italy, Sweden, Japan, and New Zealand) (Lusardi and Mitchell 2011).

In addition, the literature also shows compelling evidence in regards to financial literacy and stock market participation. Such a relationship has been documented in many parts of the world, including the Netherlands (van Rooij et al. 2011b), Switzerland (Brown and Graf 2013) and the U.S. (Yoong 2011). These findings suggest that individuals who are more knowledgeable are more likely to have more confidence and understanding of the equity market and hence have a higher participation in these more sophisticated financial markets. 
In view of the evidence from the literature, this study posits that:

$H_{1 a}$ : Financial literacy positively influences both the probability of planning for retirement, and

$H_{16}$ : allocations into high risky assets in the retirement portfolio.

\section{Risk Aversion}

Studies of personal financial behavior emphasize that an individual's risk attitude plays an important role in their financial decision making (e.g. Robiyanto and Puryandani 2015). Financial risk aversion refers to the individuals' attitude towards financial risk and reflects the level of uncertainty he or she is willing to take when making financial decisions. Kimball $(1990,54)$ explains that risk aversion describes how much one dislikes and avoids risk. In order to take a risk, risk-averse individuals would require sufficient compensation for the assumed risk. While the modern portfolio theory (Markowitz 1952) proposes that investors' portfolio allocation choices are driven by the trade-off between risk and return, investors are heterogeneous and differ in their risk-taking attitudes. For a given level of risk, investors with relatively higher levels of risk aversion will need to be compensated by higher returns than those with lower levels of risk aversion. Eeckhoudt et al. (2005) demonstrated that an individual who is more risk averse holds lower proportions of risky assets, and vice versa. This notion has been empirically supported by other researchers (e.g., Shum and Faig 2006; Chen et al. 2006; Schooley and Worden 1996). Joo and Pauwels (2002) showed evidence that individuals with lower levels of risk aversion were more confident in facing retirement. This evidence implies that individual's risk taking attitudes are crucial in understanding their financial behavior.
While the individual's financial goals are usually the main criterion in determining their financial plans, the formulation and implementation of the plans are more dependent on the individual's tolerance to risk (Grable and Carr 2014). Risk-averse individuals are expected to allocate their assets more conservatively, resulting in less accumulated assets for retirement (Bajtelsmit and Van Derhei 1997). Hence, the association between risk aversion and certain groups provides a link to understanding groups of individuals with more conservative or more aggressive approaches to retirement investment.

In this study, we argue that one who is more risk averse and dislikes risk is more likely to take the necessary precautions to ensure that their future finances are taken care of, than those who are more risk averse, who will have a higher likelihood of holding relatively lower levels of risky assets in their portfolios. Hence, this study hypothesizes the following:

$H_{2 a}:$ Risk aversion positively impacts the probability of planning for retirement, but

$H_{2 a}$ : negatively affects the allocations into bigh risky assets in the retirement portfolio.

\section{Future Expectations}

Individuals' expectations regarding the overall outlook of the economy are critical factors when an individual is making his or her financial decisions. Tarrazo and Gutierrez (2000) argue that financial planning models must take into consideration uncertainty and need to be built on the basis of expectations. This is because financial plans are forward looking, and involve agents allocating resources over time and anticipating future returns on their investments.

Continuous change in the economic climate has a marked influence on consumer 


\section{Figure 1. Conceptual Framework}

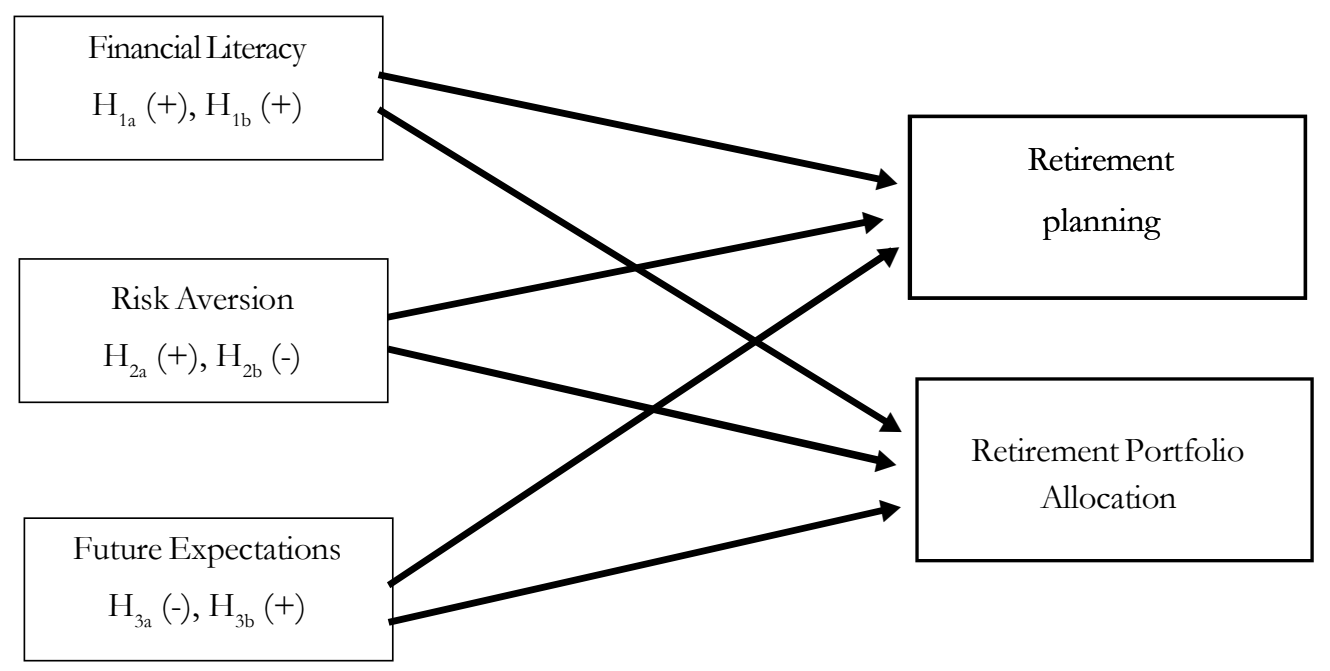

expectations of the future. Among the concerns are expectations regarding future interest rates, inflation rates, and anticipated returns on assets (Hanna et al. 2008). If the inflation rate is high, some investors may suffer from negative real returns on their savings (Fintan 2014). Such negative returns on savings will adversely affect the real income of regular savers, especially retirees, who rely heavily on savings in bank accounts. Thus, an individual's expectations regarding the future economy will affect his or her savings and investment choices. In the context of retirement planning, when expectations of the economy are positive, individuals will save less and hence, allocate lower amounts to retirement savings. Meanwhile, good expectations of the economy would increase the probability of having risky assets in their portfolios. Conversely, if expectations of the economy are negative, individuals will logically save more for their retirement and hold a lower proportion of risky assets in their portfolios. Therefore, in this study, the effect of expectations on retirement planning is examined:
$H_{3 a}$ :future expectations are negatively related to the probability of planning for retirement,

$H_{36}$ : positively related to the allocations of risky assets in the retirement portfolio.

Figure 1 shows the conceptual framework of this study, which also summarizes the hypotheses to be tested. The three independent variables (financial literacy, risk aversion, and future expectations) are posited to have a direct effect on our outcome variables namely, retirement planning and retirement portfolio allocation.

\section{Methods}

\section{Data, Sample, and Instrument}

The data for this study were collected using a self-administered questionnaire, distributed via a nonrandom convenience sampling approach among working individuals in Kuala Lumpur, Malaysia. The respondents were recruited through the researchers' personal contacts, and consisted of professionals from various industries such as manufacturing, banking, retail, and education. A sur- 
vey approach is not uncommon in financial services and retirement planning studies, and such a method of sample selection has been used among college students (e.g., Limet al. 2014), as well as working adults and professionals (e.g., Grable and Lytton 2003; Sabri and Zakaria 2015). Approximately 300 contacts were invited, via email, to participate in the study, with a link to the questionnaire hosted on Google Docs. After a month, a total of 282 responses were received; 12 were incomplete, leaving 270 usable responses for analysis. The questionnaire was worded in English and contained three main sections covering the variables in the study.

\section{Measurement of Variables}

The measurements used in this study were adapted from established scales and from the work of scholars in the area of behavioral finance and retirement studies, as follows.

\section{Dependent Variable}

\section{Retirement planning}

Retirement planning was measured using a simple binary scale modified from van Rooij et al. (2011), who used a simple measure as a rough indication of whether or not respondents had thought about and had begun planning for retirement. In this study, we ask whether or not the respondent has started to plan for retirement (yes $=1$; no $=0$ ). This type of simple measure has also been argued to be more reliable than dollar values of retirement savings, given that respondents usually do not recall or understand their own finances, leading to erroneous reporting (Athey and Kennickell 2005). Moreover, the use of a binary scale is not uncommon in financial decisions and retirement studies (e.g.,
Chatterjee and Zahirovic-Herbert 2010; Winchester et al. 2011; Alhenawi and Elkhal 2013).

\section{Retirement portfolio allocation}

Retirement portfolio allocation was measured using an ordinal scale adapted from Hochguertel et al. (1997). The question was worded as follows: "If you have started planning for your retirement, which combination of $f i$ nancial assets below best describes your retirement portfolio?" The purpose of this question was to obtain a simple estimation of the proportion of retirement portfolios allocated to lowrisk, rather than high-risk, assets. To aid respondents in answering this question, we provide a two-category classification of assets to clarify the types of financial assets that would be categorized as low risk or safe and those that would be classified as risky: (i) safe financial assets: cash, saving accounts, cashvalue life insurance; and (ii) risky financial assets: employees' provident fund; stocks/ shares, unit trusts, investment-linked insurance, commodity futures/equities. This classification was based on suggestions from past research (e.g., Hochguertel et al. 1997; Guiso et al. 1996; Bertaut and Haliassos1997).

The respondents could select one from among five categories that most appropriately describes his/her retirement portfolio:

1. All of my retirement portfolio is in safe assets

2. About three-quarters of my retirement portfolio is in safe assets

3. My retirement portfolio is balanced between safe and risky assets

4. About three-quarters of my retirement portfolio is in risky assets

5. All of my retirement portfolio is in risky assets 


\section{Independent Variables}

\section{Risk aversion}

A single item statement with a 7-point Likert scale reflecting risk aversion from van Rooij et al. (2011) measures the extent to which respondents agree or disagree with the statement that they prefer safe investments over taking on risk: 'I think it is more important to have safe investments with low, guaranteed returns; as opposed to those with high risks with some potential for high returns'. This subjective information on risk aversion, which was originally suggested by Donkers and Van Soest (1999), is a direct measure that does not require heavy cognitive processing (van Rooij et al. 2011).

\section{Future expectations}

The measure for expectations was adapted from the US National Opinion Research Centre (1996) Survey of Consumer Finances, which asks three questions about the respondents' expectations regarding the inflation rate, income level, and expectations over the next 5 years. The responses were coded 3 if the expectations were higher, 2 if expectations were about the same, and 1 if expectations were lower. The scores for the three expectation questions were added up to compute a total score.

\section{Financial literacy}

The measurement for financial literacy was based on van Rooij et al. (2011b), where five questions were asked to test the respondents' understanding and knowledge of basic financial topics such as inflation and interest gained on investments. Each question answered correctly was coded 1 , or 0 otherwise. The sum of correct answers produced a total score indicating the level of financial literacy, ranging between 0 and 5 . The ques- tions were as follows, with correct answers shown in bold:

1. Imagine that the interest rate on your savings account was 1 percent per year and inflation was 2 percent per year. After 1 year, how much you would be able to buy with the money in this account? More than today / Exactly the same / Less than today / Do not know

2. Considering a long-term period (for example, 10 or 20 years), which assets normally give the highest return? Saving accounts / Government bonds / Stocks / Do not know

3. If an investor who previously owned only two stocks decides now to spread his/her money among many different assets (i.e., more stocks, real estate), his/her risk of losing money on the entire portfolio will: Increase / Decrease / Stay the same / Do not know

4. Suppose that, in the year 2015, your income has doubled and price of all goods has doubled too. In 2015, how much will you be able to buy with your income? More than today / The same / Less than today / Do not know

5. Normally, which asset displays the highest fluctuations over time? Savings accounts / Bonds / Stocks / Do not know

The questionnaire was pretested following the recommendations in Hunt et al. (1982). We approached, (1) two academics in the field of consumer behavior and services marketing for 'expert judgement' purposes, and (2) ten working individuals who are familiar with financial matters and are involved in retirement plans that resemble the actual respondents of the study. Based on their feedback, a few minor adjustments were made, mainly to the clarity of the questionnaire's instructions. 


\section{Results}

\section{Descriptive Statistics}

A summary of the descriptive statistics is shown in Table 1. As can be seen, the sample was approximately balanced in terms of its gender and marital status, with a majority of the respondents holding a degree or professional qualification.

In regards to retirement planning, twothirds of the sample indicated that they had already started to save for their retirement. As for the question regarding their retirement portfolios' allocations, the results suggest that the respondents in the sample had a preference for low-risk assets, rather than more risky assets. Most respondents (46\%) indicated that they held 75 percent of their retirement portfolio in low-risk assets and 25 percent in risky assets. Only 1.5 percent of respondents indicated that they held 100 percent of their retirement portfolio in risky assets. The statistics suggest that the respondents are generally conservative in their investment choices and are risk averse.

Table 2 presents the summary statistics for the three main independent variables. The mean for financial literacy is 3.39 (from a maximum of 5), indicating that respondents' financial literacy is above average. The mean for risk aversion is 4.32 (from a maximum of 7 ), suggesting that the respondents in the sample are averse to risk. The financial expectations is 7.41 (from a range of 3-9) suggesting that most respondents have high expectations of the future economy. The skewness of the distribution for all three variables is within -0.5 to +0.5 , suggesting that the distribution is approximately symmetrical.
Two-sample t-tests and ANOVA tests were also conducted to test for significant differences between the demographic factors and the behavioral factors [financial literacy, risk aversion and expectations (see Table 1)]. Two-sample t-tests were conducted to examine the differences in the means of the behavioral factors with regard to gender, age, and marital status. The only statistically significant results are those with regard to gender, whereby the two-sample t-tests results suggest that females are more risk averse, compared to males $\left(\mu_{\mathrm{F}}=4.465, \mu_{\mathrm{M}}=4.165 p\right.$ $<0.05)$. Meanwhile, one-way ANOVA tests were run to test the differences in the means of the behavioral factors (financial literacy, risk aversion and expectations) in terms of the age, education, income, ethnic and religious groups of the respondents. In regards to financial literacy, the results from the ANOVA tests show that there are statistically significant differences between respondents with differing levels of education, whereby those with higher levels of education are generally more financially literate than those with lower levels $[\mathrm{F}(4,265)=4.397, p<0.01]$. The ANOVA tests also reveal statistically significant differences in the financial literacy between income groups, whereby respondents in the higher income groups display higher financial literacy scores that those in the lower income groups $[\mathrm{F}(4,265)=5.563, p<0.01]$. Interestingly, the ANOVA tests also suggest that financial literacy levels significantly differ between ethnic groups, whereby those from the Indian and Chinese ethnic groups appear to have higher financial literacy scores as opposed to the Malays and those from the other groups $[\mathrm{F}(3,266)=13.226, p<0.01]$. Likewise, the ANOVA tests indicate that the financial literacy levels among the religious 
Table 1.Descriptive Statistics of Demographic Variables and Mean Differences Among Categories for Financial Literacy, Risk Aversion and Expectations

\begin{tabular}{|c|c|c|c|c|c|c|c|c|}
\hline \multirow[t]{2}{*}{ Variables } & & \multirow[t]{2}{*}{$\begin{array}{c}\text { Frequency } \\
(\%) \\
(n=270)\end{array}$} & \multicolumn{2}{|c|}{$\begin{array}{c}\text { Financial } \\
\text { Literacy }\end{array}$} & \multicolumn{2}{|c|}{ Risk Aversion } & \multicolumn{2}{|c|}{ Expectations } \\
\hline & & & $\begin{array}{l}\text { Mean } \\
\text { (SD) }\end{array}$ & $\begin{array}{l}\text { Test } \\
\text { Static }\end{array}$ & $\begin{array}{l}\text { Mean } \\
\text { (SD) }\end{array}$ & $\begin{array}{l}\text { Test } \\
\text { Static }\end{array}$ & $\begin{array}{l}\text { Mean } \\
\text { (SD) }\end{array}$ & $\begin{array}{l}\text { Test } \\
\text { Static }\end{array}$ \\
\hline Gender & & & \multicolumn{2}{|c|}{$\mathrm{t}=2.208$} & \multicolumn{2}{|c|}{$t=-1.656^{*}$} & \multicolumn{2}{|c|}{$\mathrm{t}=2.419$} \\
\hline & $\begin{array}{l}\text { - Female } \\
\text { - Male }\end{array}$ & $\begin{array}{l}142(52.6) \\
128(47.4)\end{array}$ & \multicolumn{2}{|c|}{$\begin{array}{l}3.232(1.247) \\
3.570(1.265)\end{array}$} & \multicolumn{2}{|c|}{4.465 (1.442) } & \multicolumn{2}{|c|}{$\begin{array}{l}7.261(1.096) \\
7.586(1.112)\end{array}$} \\
\hline Age & & & \multicolumn{2}{|c|}{$\mathrm{F}=0.952$} & \multicolumn{2}{|c|}{$\mathrm{F}=2.743^{* * *}$} & \multicolumn{2}{|c|}{$\mathrm{F}=0.875$} \\
\hline & $\begin{array}{l}\text { (1) } 20 \text { to } 30 \\
\text { (2) } 31 \text { to } 40 \\
\text { (3) } 41 \text { to } 50 \\
\text { (4) } 51 \text { to } 60\end{array}$ & $\begin{array}{c}65(24.1) \\
138(51.1) \\
50(18.5) \\
17(6.3)\end{array}$ & $\begin{array}{l}3.185 \\
3.500 \\
3.400 \\
3.294\end{array}$ & $\begin{array}{l}1.424) \\
1.192) \\
1.229) \\
1.312)\end{array}$ & $\begin{array}{l}4.262 \\
4.036 \\
5.120 \\
4.529\end{array}$ & $\begin{array}{l}1.461) \\
1.452) \\
1.438) \\
1.375)\end{array}$ & $\begin{array}{l}7.508 \\
7.326 \\
7.580 \\
7.294\end{array}$ & $\begin{array}{l}0.921) \\
1.172) \\
1.071) \\
1.404)\end{array}$ \\
\hline \multirow[t]{2}{*}{ Level of Education } & & & \multicolumn{2}{|c|}{$\mathrm{F}=4.397 * * *$} & \multicolumn{2}{|c|}{$\mathrm{F}=1.829$} & \multicolumn{2}{|c|}{$\mathrm{F}=0.146$} \\
\hline & $\begin{array}{l}\text { - Secondary school } \\
\text { - Diploma/certificate } \\
\text { - Degree/professional } \\
\text { - Postgraduate (Masters/PhD) } \\
\text { - Other }\end{array}$ & $\begin{array}{c}10(3.7) \\
41(15.2) \\
160(59.3) \\
58(21.5) \\
1(4)\end{array}$ & $\begin{array}{r}3.200 \\
2.976 \\
3.400 \\
3.759 \\
0 .\end{array}$ & $\begin{array}{l}1.033) \\
1.151) \\
1.285) \\
1.174) \\
00\end{array}$ & $\begin{array}{r}4.400 \\
4.537 \\
4.369 \\
3.983 \\
7 .\end{array}$ & $\begin{array}{l}1.578) \\
1.227) \\
1.544) \\
1.469) \\
00\end{array}$ & $\begin{array}{r}7.300 \\
7.146 \\
7.413 \\
7.655 \\
6.1\end{array}$ & $\begin{array}{l}1.636) \\
1.256) \\
1.024) \\
1.117) \\
00\end{array}$ \\
\hline Marital Status & & & $\mathrm{t}=$ & 803 & $\mathrm{t}=$ & 738 & $\mathrm{t}=-$ & .705 \\
\hline & $\begin{array}{l}\text { - Single } \\
\text { - Married }\end{array}$ & $\begin{array}{l}146(54.1) \\
124(45.9)\end{array}$ & $\begin{array}{l}3.336 \\
3.460\end{array}$ & $\begin{array}{l}1.341) \\
1.171)\end{array}$ & $\begin{array}{l}4.260 \\
4.395\end{array}$ & $\begin{array}{l}1.419) \\
1.581)\end{array}$ & & \\
\hline Children & & & $\mathrm{t}=$ & .056 & $\mathrm{t}=$ & 680 & $\mathrm{t}=$ & .338 \\
\hline & $\begin{array}{l}\text { - Have children } \\
\text { - Do not have children }\end{array}$ & $\begin{array}{l}159(58.9) \\
111(41.1)\end{array}$ & $\begin{array}{l}3.387 \\
3.396\end{array}$ & $\begin{array}{l}1.222) \\
1.298)\end{array}$ & $\begin{array}{l}4.505 \\
4.195\end{array}$ & $\begin{array}{l}1.606) \\
1.403)\end{array}$ & $\begin{array}{l}7.387 \\
7.434\end{array}$ & $\begin{array}{l}1.222) \\
1.034)\end{array}$ \\
\hline Monthly Income & & & $\mathrm{F}=5$. & $63^{* * *}$ & $\mathrm{~F}=$ & 391 & $\mathrm{~F}=2$ & 013* \\
\hline & $\begin{array}{l}\text { (1) } \leq \text { RM2,500 } \\
\text { (2) RM2,501-RM5,000 } \\
\text { (3) RM5,001-RM7,500 } \\
\text { (4) RM7,501-RM10,000 } \\
\text { (5) } \geq \text { RM10,001 }\end{array}$ & $\begin{array}{r}25(9.3) \\
72(26.7) \\
90(33.3) \\
40(14.8) \\
43(15.9)\end{array}$ & $\begin{array}{l}2.600 \\
3.111 \\
3.567 \\
3.525 \\
3.837\end{array}$ & $\begin{array}{l}1.190) \\
1.273) \\
1.171) \\
1.320) \\
1.174)\end{array}$ & $\begin{array}{l}4 . \\
4 . \\
4 . \\
4 . \\
4 .\end{array}$ & $\begin{array}{l}20 \\
47 \\
11 \\
25 \\
16\end{array}$ & $\begin{array}{l}7 . \\
7 . \\
7 . \\
7 . \\
7 .\end{array}$ & $\begin{array}{l}20 \\
39 \\
00 \\
75 \\
95\end{array}$ \\
\hline Ethnicity & & & $\mathrm{F}=13$ & $226^{* * *}$ & $\mathrm{~F}=13$ & $01 * * *$ & $\mathrm{~F}=$ & .755 \\
\hline & $\begin{array}{l}\text { - Malay } \\
\text { - Chinese } \\
\text { - Indian } \\
\text { - Other }\end{array}$ & $\begin{array}{c}116(43.0) \\
118(43.7) \\
30(11.1) \\
6(2.2)\end{array}$ & $\begin{array}{l}2.931 \\
3.780 \\
3.867 \\
2.333\end{array}$ & $\begin{array}{l}1.185) \\
1.103) \\
1.383) \\
1.751)\end{array}$ & $\begin{array}{l}4.888 \\
3.746 \\
4.433 \\
4.167\end{array}$ & $\begin{array}{l}1.479) \\
1.360) \\
0.935) \\
2.483)\end{array}$ & $\begin{array}{l}7.500 \\
7.356 \\
7.333 \\
7.333\end{array}$ & $\begin{array}{l}1.067) \\
1.106) \\
1.348) \\
1.033)\end{array}$ \\
\hline Religion & & & $\mathrm{F}=8$. & $07 * * *$ & $\mathrm{~F}=8$ & $53 * * *$ & $\mathrm{~F}=2$ & $795^{* *}$ \\
\hline & $\begin{array}{l}\text { - Muslim } \\
\text { - Buddhist } \\
\text { - Christian } \\
\text { - Hindu } \\
\text { - Other }\end{array}$ & $\begin{array}{c}116(43.0) \\
84(31.1) \\
22(8.1) \\
12(4.4) \\
36(13.3)\end{array}$ & $\begin{array}{l}2.931 \\
3.786 \\
3.500 \\
4.091 \\
3.500\end{array}$ & $\begin{array}{l}1.185) \\
1.109) \\
1.243) \\
1.065) \\
1.483)\end{array}$ & $\begin{array}{l}4.888 \\
3.857 \\
4.500 \\
4.046 \\
3.694\end{array}$ & $\begin{array}{l}1.479) \\
1.390) \\
1.314) \\
0.999) \\
1.489)\end{array}$ & $\begin{array}{l}7.500 \\
7.452 \\
8.000 \\
6.864 \\
7.194\end{array}$ & $\begin{array}{l}1.067) \\
1.080) \\
0.739) \\
1.356) \\
1.167)\end{array}$ \\
\hline
\end{tabular}


Table 1. Continued

\begin{tabular}{llc}
\hline Variables & & $\begin{array}{c}\text { Frequency }(\boldsymbol{n}=\mathbf{2 7 0}), \\
\text { Percent (\%) }\end{array}$ \\
\hline Retirement Planning & - Yes & $180(66.7)$ \\
& - No & $90(33.3)$ \\
Retirement Portfolio & $-100 \%$ safe & \\
Allocation & $-75 \%$ safe, $25 \%$ risky & $26(9.6)$ \\
& $-50 \%$ safe, $50 \%$ risky & $125(46.3)$ \\
& $-25 \%$ safe, $75 \%$ risky & $74(27.4)$ \\
& $-100 \%$ risky & $41(15.2)$ \\
& & $4(1.5)$ \\
\hline
\end{tabular}

Note:

(1) Two sample t-tests were conducted to test the differences in means for independent variables with two categories (t-values are reported).

(2) ANOVA tests were conducted to test the differences in means for independent variables with three or more categories (Fvalues are reported).

(3) $* * *, * *$, and $*$ refer to $\mathrm{p}<0.01, \mathrm{p}<0.05$, and $\mathrm{p}<0.10$, respectively.

Table 2. Summary Statistics for Independent Variables

\begin{tabular}{lcccccc}
\hline Variable & Mean & Std. Deviation & Min. & Max. & Skewness & Kurtosis \\
\hline $\begin{array}{l}\text { Financial } \\
\text { Literacy }\end{array}$ & 3.39 & 1.26 & 0 & 5 & -0.47 & 2.52 \\
Risk aversion & 4.32 & 1.49 & 1 & 7 & -0.07 & 2.42 \\
Expectation & 7.41 & 1.11 & 3 & 9 & -0.34 & 2.69 \\
\hline
\end{tabular}

groups also significantly differ, whereby the highest financial literacy scores were reported from the Hindu and Buddhist groups and the lowest financial literacy score was reported by the Muslim group $[\mathrm{F}(4,265)=8.507, p<$ $0.01]$. Some of our results were consistent with a study in the southern part of Italy by Bajo et al. (2015) in which financial literacy was found to be lower amongst women, the less educated and also, the less wealthy.

The ANOVA tests results also show statistically significant differences in the risk aversion levels between ethnic and religious groups. The Malays appear to have the highest risk aversion scores compared to the other ethnic groups $[\mathrm{F}(3,266)=13.001, p<0.01]$. Similarly, the Muslim group displays the highest risk aversion score compared to the other religious groups $(\mathrm{F}(4,265)=8.953, p<0.01)$, suggesting that the Malays and Muslims are the ones most likely to avoid high risk investments. The results of the ANOVA tests also imply significant differences in the risk aversion levels of respondents in different age 
groups $[\mathrm{F}(3,266)=2.743, p<0.01]$. Respondents within the range of 41-50 display the highest risk aversion level, followed by the highest age range of 51-60.

\section{Multivariate Analyses}

\section{Retirement planning}

For the first research objective dealing with $H_{1 a}, H_{2 a}$, and $H_{3 a}$, we examined the factors that influence the probability of planning for retirement using a logistic regression model. This model seems to be suitable, given the nature of the dependent variable, which indicates whether or not the respondents had started saving for their retirement. Surveybased research commonly uses a binary logistic regression, where the dependent variable is dichotomous in nature and denotes an event or nonevent. In studies of retirement planning and financial literacy, the use of logistic models has also been widely employed (e.g., Volpe and Chen 1998; Alhenawi and Elkhal 2013)

The logistic regression model estimates the effect of certain explanatory variables on a variable $y^{*}$, which, in this case, is the propensity of being prepared for retirement. The latent variable model can be expressed as:

$$
y_{i}^{*}=\alpha+\beta Z_{i}+\varepsilon_{i}
$$

where $y_{i}^{*}$ is the unobserved individual propensity to save for retirement, $\beta Z_{i}$ is a vector of the independent variables (financial literacy, risk aversion, expectations, and the control variables) observed for individual $i, \alpha$ and $\beta$ are the parameters to be estimated, and the $\varepsilon_{i}$ are the unobserved error terms assumed to be independent of the other explanatory variables. We ran the logistic regression and the results are shown in Table 3.

Table 3. Logistic Regression on Retirement Planning and Ordered Probit Regression on Retirement Portfolio Allocation Choice

\begin{tabular}{lcc}
\hline \multirow{2}{*}{ Variable } & $\begin{array}{c}\text { Model 1: } \\
\text { Retirement Planning }\end{array}$ & $\begin{array}{c}\text { Model 2: Retirement } \\
\text { Portfolio Allocation }\end{array}$ \\
\cline { 2 - 3 } & $\begin{array}{c}\text { Odds Ratio } \\
\text { (S.E) }\end{array}$ & $\begin{array}{c}\text { Coefficients } \\
\text { (S.E) }\end{array}$ \\
\hline Behavioural Factors & & \\
Literacy & 1.136 & $0.126^{* * *}$ \\
& $(0.145)$ & $(0.084)$ \\
Risk Aversion & 0.979 & $-0.247^{* * *}$ \\
Expectation & $(0.106)$ & $(0.070)$ \\
& $1.440 * * *$ & -0.047 \\
Demographic Variables & $(0.199)$ & $(0.080)$ \\
Gender (Male) & & \\
Education & & \\
& 0.669 & $0.364^{* * *}$ \\
Marital & $(0.209)$ & $(0.184)$ \\
& 1.086 & -0.051 \\
& $(0.427)$ & $(0.130)$ \\
& 1.186 & $0.456^{*}$ \\
& $(0.427)$ & $(0.267)$ \\
& & \\
\hline
\end{tabular}


GadjahMada International Journal of Business-September-December, Vol. 19,No. 3, 2017

Table 2. Continued

\begin{tabular}{|c|c|c|}
\hline & $\begin{array}{c}\text { Model 1: } \\
\text { Retirement Planning }\end{array}$ & $\begin{array}{l}\text { Model 2: Retirement } \\
\text { Portfolio Allocation }\end{array}$ \\
\hline Variable & $\begin{array}{l}\text { Odds Ratio } \\
\quad \text { (S.E) }\end{array}$ & $\begin{array}{l}\text { Coefficients } \\
\text { (S.E) }\end{array}$ \\
\hline Children & $\begin{array}{c}0.892 \\
(0.407)\end{array}$ & $\begin{array}{l}-0.516^{*} \\
(0.273)\end{array}$ \\
\hline Malay & $\begin{array}{c}1.634 \\
(0.797)\end{array}$ & $\begin{array}{c}0.375 \\
(0.322)\end{array}$ \\
\hline Chinese & $\begin{array}{c}1.796 \\
(0.854)\end{array}$ & $\begin{array}{c}0.445 \\
(0.299)\end{array}$ \\
\hline Other & $\begin{array}{c}0.523 \\
(0.531)\end{array}$ & $\begin{array}{c}0.698 \\
(0.721)\end{array}$ \\
\hline \multicolumn{3}{|l|}{ Age } \\
\hline 20 to 30 & $\begin{array}{c}0.148 * * \\
(0.133)\end{array}$ & $\begin{array}{c}0.450 \\
(0.385)\end{array}$ \\
\hline 31 to 40 & $\begin{array}{l}0.216^{*} \\
(0.184)\end{array}$ & $\begin{array}{c}-0.051 \\
(0.331)\end{array}$ \\
\hline 41 to 50 & $\begin{array}{c}0.501 \\
(0.455)\end{array}$ & $\begin{array}{l}-0.395 \\
(0.353)\end{array}$ \\
\hline \multicolumn{3}{|l|}{ Financial Variables } \\
\hline \multicolumn{3}{|l|}{ Income: } \\
\hline RM2,501-RM5,000 & $\begin{array}{c}1.829 \\
(0.936)\end{array}$ & $\begin{array}{c}0.049 \\
(0.414)\end{array}$ \\
\hline RM5,001-RM7,500 & $\begin{array}{l}2.830 * \\
(1.569)\end{array}$ & $\begin{array}{c}0.307 \\
(0.420)\end{array}$ \\
\hline RM7,501-RM10,000 & $\begin{array}{l}5.236^{* *} \\
(3.432)\end{array}$ & $\begin{array}{c}0.433 \\
(0.447)\end{array}$ \\
\hline$\geq \mathrm{RM} 10,001$ & $\begin{array}{l}2.991 * \\
(1.956)\end{array}$ & $\begin{array}{c}0.557 \\
(0.461)\end{array}$ \\
\hline \multicolumn{3}{|l|}{ Thresholds } \\
\hline$\mu_{1}$ & & $\begin{array}{l}-1.785 \\
(0.946)\end{array}$ \\
\hline$\mu_{2}$ & & $\begin{array}{l}-0.027 \\
(0.938)\end{array}$ \\
\hline$\mu_{3}$ & & $\begin{array}{c}0.934 \\
(0.940)\end{array}$ \\
\hline$\mu_{4}$ & & $\begin{array}{c}2.213 \\
(0.963)\end{array}$ \\
\hline
\end{tabular}


Table 2. Continued

\begin{tabular}{lcc}
\hline Variable & $\begin{array}{c}\text { Model 1: } \\
\text { Retirement Planning }\end{array}$ & $\begin{array}{c}\text { Model 2: Retirement } \\
\text { Portfolio Allocation }\end{array}$ \\
\cline { 2 - 3 } & $\begin{array}{c}\text { Odds Ratio } \\
\text { (S.E) }\end{array}$ & $\begin{array}{c}\text { Coefficients } \\
\text { (S.E) }\end{array}$ \\
\hline $\mathrm{LR} \mathrm{Chi}^{2}(17)$ & 44.43 & 202.708 \\
Probability $>\mathrm{chi}^{2}$ & 0.0003 & $0.000^{* * *}$ \\
Pseudo ${ }^{2}$ & 0.1293 & 0.1258 \\
$\mathrm{n}$ & 270 & 180 \\
\hline
\end{tabular}

\section{Note:}

(1) Model 1: Dependent variable is the odds ratio of planning for retirement versus not planning for retirement.

(2) Model 2: Dependent variable is the portfolio allocation choice of 5 categories.

(3) Income 1 is the base group for Income, Age 4 is the base group for Age, Indian is the base group for Ethnicity.

(4) $* * *, * *$, and $*$ refer to $\mathrm{p}<0.01, \mathrm{p}<0.05$, and $\mathrm{p}<0.10$, respectively.

To test the overall goodness-of-fit of the model, we employed the HosmerLemeshow test by collapsing the observations with the same predicted probabilities into ten groups (Hosmer et al. 2013). The results indicate that $\chi^{2}=12.62$. A probability $>\chi^{2}=$ 0.1255 indicates that the model cannot be rejected, and that the goodness-of-fit of the model is reasonable. The likelihood ratio $\chi^{2}$ of $44.43(p<0.01)$ suggests that the overall fit of the model is significantly better than that of a model with no explanatory variables.

Out of the three main variables of interest, only expectations yielded significant results. The results for expectations are positive, suggesting that individuals with more positive expectations of the future economy are more likely to having started to plan for their retirement $(O R=1.44, p<0.01)$. This contradicts the apriori notion that people who are more pessimistic about the future economic conditions are more likely to save for their future and have a retirement plan. None- theless, a possible explanation is that the group of individuals with positive future expectations may have more confidence in the financial system and would, hence, safely set aside their retirement savings in preparation for the future.

The relationship between the two other independent variables - financial literacy and risk aversion - and the odds of being prepared for retirement were found to be statistically insignificant. Although the sign of the odds ratio for financial literacy supports our earlier prediction that higher financial literacy increases the odds of planning for retirement, the relationship is not significant $(O R=1.14$, $p>0.10)$. This means that, whether or not an individual is financially literate does not determine the likelihood of them planning for their retirement, contradicting prior studies that have found significant positive relationships (e.g., Sekita 2011; Boisclair et al. 2015; van Rooij et al. 2012; Brown and Graf 2013). One possible explanation is that most 
private sector employees in Malaysia are still bound by defined benefit plans under the Employee Provident Fund (EPF), in which contributions by employees and employers are mandatory. Therefore, regardless of their financial literacy levels, the working respondents would already have a retirement plan implemented, via their mandatory contributions to the Employees Provident Fund (EPF).

Similar insignificant results are seen for risk aversion $(\mathrm{OR}=0.979, p>0.1)$. This result suggests that the level of risk aversion does not appear to influence an individual's retirement planning. The result contradicts that of Joo and Pauwels (2002), which indicated that individuals with lower levels of risk aversion are more confident about facing retirement. This result may be due to the fact that the retirement funds of employees are mainly defined benefit plans managed through the EPF. Hence, the contributors' risk aversion levels do not play a significant role in their level of planning. From the above results, we conclude that the evidence is insufficient to support $H_{1 a}, H_{2 a}$ and $H_{3 a}$.

The results indicate some significant relationships between demographic variables and retirement preparedness. Of the control variables, income and age significantly impact the odds ratio of having a retirement plan. The results imply that higher income earners have a higher probability of having a retirement plan compared to the people in the lowest income category. The findings also reveal a significant impact of age on the odds of having a retirement plan. The results suggest that younger respondents were more likely to have a retirement plan than their older counterparts. These results support mass media reports that a significant number of elderly Malaysians are not financially prepared for retirement. A possible explanation is that older individuals who are approaching retirement age perceive themselves as not having a plan for retirement, due to the imminent alarming reality of having no income to support them during retirement.

\section{Retirement portfolio allocation choice}

To deal with the second objective of this study, we selected respondents who indicated a positive response to retirement planning, separating out those who did not. From the 270 responses, ninety observations were disregarded and 180 observations were used for further analysis. We employed an ordered probit regression model to examine the second research objective regarding the determinants of the retirement portfolio allocation choice. The ordered probit model is suitable for modelling dependent variables with categories of some qualitative rank order. In this case, respondents could have a retirement portfolio containing zero percent risky assets, about a quarter of their portfolio in risky assets, about half in risky assets, about three quarters in risky assets; or the entire portfolio in high-risk assets. These categories represent an ordered form, but with no fixed magnitudes among the categories.

We estimate the ordered probit model using the following specification:

$$
\mathrm{T}_{\mathrm{i}}^{*}=\beta z_{\mathrm{i}}+\varepsilon_{\mathrm{i}}
$$

where $T_{i}^{*}$ represents the dependent variable, which is the percentage of risky assets held; for respondent $i, z_{i}$ is a vector of the explanatory variables denoting the behavioral aspects under consideration (financial literacy, risk aversion and expectations), $\beta$ is the vector of parameters for estimation, and $\varepsilon_{i}$ is the random error term that is assumed to be normally distributed. The actual percentage of risky assets held, $T_{i}^{*}$, is censored at 0 and 1 , 
as the total portfolio equals 100 percent and the respondents may hold anything between 0 percent and 100 percent of risky assets in their retirement portfolio.

The portfolio allocation with ordered categories, $T_{i}$ is determined from the model as follows:

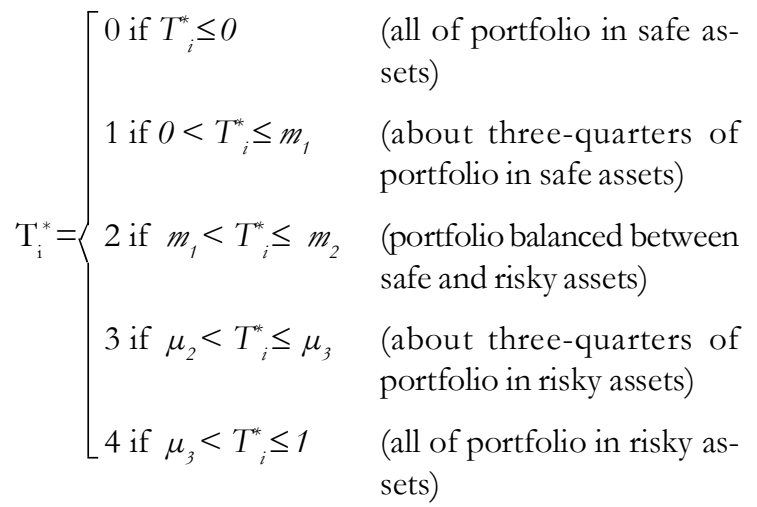

where $\mu_{1}$ represents the thresholds to be estimated together with the parameter vector $\beta$.

The results of the overall model indicate that the likelihood ratio $\chi^{2}$ is 202.70 ( $p$ $<0.01$ ) (Table 3 ). This suggests that the overall model is acceptable, as it fits significantly better than a model with no predictors. The findings from the ordered probit model demonstrate that financial literacy and risk aversion are significant determinants of the retirement portfolio allocation choice. The findings indicate that the marginal effect of a one unit increase in financial literacy increases the odds of having a higher allocation of risky assets $(\beta=0.13, p<0.05)$, supporting $H_{16}$. The results are consistent with other studies conducted in the context of other countries, such as the studies by van Rooij et al. (2011b), Yoong (2011), and Brown and Graf (2013), which show positive relationships between higher financial literacy and stock market participation. The results of this study imply that Malaysians who are more financially knowledgeable have a better understanding of risky assets, and hence would have higher proportions of risky asset holdings in their portfolios than those who are financially illiterate.

Meanwhile, the results suggest that individuals who are more risk averse will have a lower likelihood of holding a higher portion of risky assets in their portfolios, as shown by the negative sign of coefficient $(\beta=-0.25$, $p<0.01)$. These results support $H_{2 b}$ and are consistent with theoretical and empirical evidence that suggest a negative relationship between risk aversion and the holding of risky assets (e.g., Markowitz 1952; Eeckhoudt et al. 2005; Shum and Faig 2006; Chen et al. 2006; Schooley and Worden 1996; Bajtelsmit and Vanderhei 1997). The results of this study imply that individuals who are more risk averse have more confidence holding risky assets in their portfolios. Meanwhile, expectations of the future were found to be irrelevant to the determination of a retirement portfolio allocation; there is thus no evidence to support $H_{3 b}$.

The positive coefficient for gender suggests that male respondents are more likely to have a higher proportion of risky assets in their retirement portfolios $(\beta=0.42, p<$ 0.01 , supporting the findings of past researchers who demonstrated that men display more risk-taking behavior and have a higher probability of holding risky assets (e.g., Grable 2013, Sapienza et al. 2009; Bernasek and Shwiff 2001; Jianakoplos and Bernasek 1998; Palsson 1996).

The results also show that individuals who are married have a higher probability of holding riskier portfolios than those who are single or divorced $(\beta=0.36 ; p<0.1)$. A likely reason for this result is that individuals who are married may perhaps have income buffers from their spouses, and hence have more confidence investing in risky assets than single 
or divorced individuals. However, those who had children had a lower probability of holding risky assets in their portfolios $(\beta=-0.52$, $p<0.1)$. The rationale behind this could be due to having more dependents under one's care leads to more conservative investment strategies.

\section{Discussion and Conclusion}

In this study, the impact of behavioral factors on retirement planning decisions was investigated. This paper was built upon the notion that retirement planning involves a complex interaction of behavioral factors and financial skills; thus it contributes to the literature by providing a comprehensive model that integrates these important elements that are required for long-term financial planning. Furthermore, the paper explored the determinants of retirement portfolio choice, which is still an under examined area, and introduced a simple ordinal measurement to provide a rough indication of the proportion of risky assets held in a retirement savings portfolio.

In regards to the first research objective, the findings of this study reveal that income, age, and future expectations are significantly related to the likelihood of having a retirement plan. In regards to the second research objective, individuals with higher levels of $f i$ nancial literacy and risk aversion, as well as male and married individuals, have a higher likelihood of holding larger proportions of risky assets in their portfolios.

Contradicting prior expectations, this study reveals that those who are more positive about the future, in terms of the economy, are the ones who are more likely to plan for their retirement. While the expected sign of relationship contradicts a priori, the significance of this variable supports the literature suggesting that individuals incorporate uncertainty and expectations into their financial decision making and planning (Tarrazo and Gutierrez 2000). Expectations are important, as financial plans are long term in nature and are exposed to numerous internal and external forces that may disrupt the intended objectives of these plans. A possible explanation for the positive impact of expectations and retirement planning is that individuals with positive future expectations have more confidence in the financial system and can safely set aside their retirement savings in preparation for the future. In view of the indeterminate global economic environment, it is thus important for the government and policy makers to instill confidence in investors regarding the future of the Malaysian economy, as this would also boost their confidence in saving for the long-term in the Malaysian financial market. It is also important for financial services marketers to educate the public regarding long term investments and the importance of planning for retirement, despite the volatile conditions of the economy. From the descriptive analyses, it is possible to identify the characteristics of respondents that have lower expectations of the economy, hence, policy makers should target these groups of people to boost their prospects and confidence and expectations of the Malaysian economy.

One of the main results of this study is that financial literacy impacts the retirement portfolio allocation choice. This finding supports past studies which have found financial literacy to have an impact on participation in high risk assets such as stocks and shares (e.g. van Rooij et al. 2011b; Brown and Graf 2013; Yoong 2011). In addition, this study has found that, generally, those with lower financial literacy are female, in the lower 
income groups and are Malays and Muslims. Hence, the regulators, policy makers and financial planners from the financial services industry should target these groups of people to provide more financial education with the aim of improving their decisions on retirement allocations.

In view of the fact that the responsibility for having adequate retirement savings has shifted from governments and employers to the individuals themselves, it is thus important for individuals to be equipped with more skills and financial knowledge, if they are to ensure that the plans they make meet their desired objectives. Defined contribution plans, such as the Private Retirement Scheme (PRS) is still considered to be in their initial stage in Malaysia. Hence, significant efforts should be implemented to increase individuals' participation in these plans to ensure that retirement goals are achieved.

Our results also indicate that those who are more risk averse are less likely to hold risky assets in their portfolios, supporting past studies (Shum and Faig 2006; Chen et al. 2006; Schooley and Worden 1996; Grable and Carr 2014). In addition, results also reveal that those who are more risk averse tend to be female, within the age group of 41-50 years old, and from the Malay ethnic group. Hence, financial services providers should try to attract these segment groups by designing medium-term fixed income investments to suit their risk tolerance levels. Introducing additional retirement savings instruments that are able to reduce the complexity of investment decisions and offer some assurance and protection against economic uncertainties, may go a long way in giving financial security to those who are less risk tolerant. Malaysia's Employees Provident Fund (EPF) should leverage this information to properly assess investors according to their risk tolerance lev- els, in order to encourage them to allocate their investments into the Private Retirement Scheme (PRS), which is a defined contribution plan that offers a variety of funds for investors to select, according to their risk appetites. The scheme, which was introduced in 2011, can still be considered very new and remains relatively untapped, with much potential for growth.

This study has found that males were more likely to hold higher portions of risky assets in their portfolios, supporting the findings of other studies that have found men to be more risk tolerant than women (e.g., Chong et al. 2012; Duasa and Yusof 2013). This signals a good opportunity for financial marketers to target the female segment and educate them on the various financial products according to risk and return. In fact, TheFinancialBrand.com (2013) indicates that marketing from financial institutions has fallen short, in terms of connecting with women on a more personal level, making them the least ventured market. The report further highlighted that boomer women may be a lucrative segment, having not only an interest in financial services but also the resources to use them; however, financial marketers have failed to take this opportunity.

The findings also reveal that the Malay and Muslim groups are among the least financially literate and are also the most risk averse. Financial services providers can target this group to increase their financial literacy and educate them on the various financial products with different risks and returns. As Malaysia is expected to become an aged nation in the next two decades (Global AgeWatch Index 2015), it is hoped that this study will shed light on the importance of retirement planning and adequate savings, because evidently, those with lower financial literacy and higher risk aversion are less likely 
to hold high risk assets in their portfolios. With proper promotion and consumer education, investors should have the benefits of portfolio diversification explained to them, in order for them to meet their long term financial objectives.

Finally, no study is without limitations. Owing to the exploratory nature of the study, we acknowledge the fact that the sample was rather small and limited only to urban working Malaysians in Kuala Lumpur. Hence, the respondents can be assumed to have been more exposed to financial matters than those in suburban or rural areas. Increasing the sample size to include different demographics is certainly recommended for the purposes of generalization and representation. In order to encapsulate the diversity of the country, we recommend that the sample be extended to a wider audience. For example, with regards to ethnicity, our study was limited only to the three main ethnic groups (Malaysians, Indians, and Chinese) whilst there are other ethnicities in East Malaysia. Besides that, future studies can also collaborate with policy makers, such as the government and the employees' provident fund agencies, to capture both public and private sector employees. This will not only benefit them, but also the nation as a whole, in ensuring the sustainability of the wealth and prosperity of its citizens.

\section{Acknowledgements}

We would like to acknowledge the financial support provided by the Ministry of Higher Education Malaysia under the Fundamental Research Grant Scheme (FRGS) No.FP025-2016, and also the Social Security Research Center (SSRC) (UM.E/SSRC/628/3/2) of University of Malaya, for guidance and support.

\section{References}

Alhenawi, Y., and K. Elkhal. 2013. Financial literacy of US households: Knowledge vs. long-term financial planning. Financial Services Review 22: 211-244.

Athey, L. A., and A. B. Kennickell. 2005. Managing data quality on the 2004 survey of consumer finances. In Annual Meetings of the American Association for Public Opinion Research. Miami Beach, Florida, May $12-15$.

Bajo, E., M. Barbi, and S. Sandri. 2015. Financial literacy, households' investment behavior, and risk propensity. Journal of Financial Management, Markets and Institutions 3 (1): 157-174.

Bajtelsmit, V. L., and J. L. Van Derhei. 1997. Risk aversion and pension investment choices. Positioning Pensions for the Twenty-First Century 45: 66.

Bernasek, A., and S. Shwiff. 2001. Gender, risk, and retirement. Journal of Economic Issues 35 (2): 345-356.

Bertaut, C. C., and M. Haliassos. 1997. Precautionary portfolio behavior from a life-cycle perspective. Journal of Economic Dynamics and Control 21 (8): 1511-1542.

Boisclair, D., A. Lusardi, and P. C. Michaud. 2015. Financial literacy and retirement planning in Canada. Journal of Pension Economics and Finance 1-20. 
Brown, M., and R. Graf. 2013. Financial literacy and retirement planning in Switzerland. Numeracy 6 (2): 6.

Burnett, J., K. Davis, C. Murawski, R. Wilkins, and N. Wilkinson. 2013. Measuring retirement savings adequacy in Australia. JASSA 4: 28.

Chatterjee, S., and V. Zahirovic-Herbert. 2010. Retirement planning of younger baby-boomers: Who wants financial advice? Financial Decisions 22 (2): 1-12.

Chen, P., R. G. Ibbotson, M. A. Milevsky, and K. X. Zhu. 2006. Human capital, asset allocation, and life insurance. Financial Analysts Journal62 (1): 97-109.

Chin, Christina. 2015. Many senior citizens still cannot afford to retire. The Star Online. Retrieved from http://www.thestar.com.my/News/Nation/2015/08/02/Many-senior-citizens-still-cannot-affordto-retire/

Chong, S. C., W. W. Cheong, B. K. Sia, and K. K. Ng. 2012. Perception of financial risk tolerance of older urban Chinese in Malaysia. International Journal of Academic Research 4: 28-23.

Duasa, J., and S. A. Yusof. 2013. Determinants of risk tolerance on financial assets ownership: A Case of Malaysia. International Journal of Business and Society 14 (1): 1-16.

Donkers, B., and A. van Soest. 1999. Subjective measures of household preferences and financial decisions. Journal of Economic Psychology 20: 613-642.

Eeckhoudt, L., C. Gollier, and H. Schlesinger. 2005. Economic and Financial Decisions under Risk. Princeton University Press.

Fintan, Ng. 2014. Savings now impacted by inflation. The Star Online (January 25). Retrieved from http:/ /www.thestar.com.my/Business/Business-News/2014/01/25/Savings-now-impacted-by-inflation-will-OPR-be-revised-with-expected-price-hikes $/$ ?style $=$ biz

Gallery, N., G. Gallery, K. Brown, C. Furneaux, and C. Palm. 2011. Financial literacy and pension investment decisions. Financial Accountability and Management 27 (3): 286-307.

Ghilarducci, T., J. Saad-Lessler, and K. Bahn. 2015. Are US workers ready for retirement? Trends in plan sponsorship, participation, and preparedness. Journal of Pension Benefits (Winter 2015. 25-39). Ferenczy Benefits Law Center. Available at http://ssrn.com/abstract $=2604299$

Global AgeWatch Index 2015. Population Ageing Maps. Available at: http://www.helpage.org/globalagewatch/population-ageing-data/population-ageing-map/

Grable, J. E. 2013. Gender, wealth, and risk: Why are baby boomer women less risk tolerant than baby boomer men? Journal of Financial Service Professionals 67 (3): 7-9.

Grable, J. E., and N. A. Carr. 2014. Risk tolerance and goal-based financial planning. Journal of Financial Service Professionals 68 (1): 12-14.

Grable, J. E., and R. H. Lytton. 2003. The development of a risk assessment instrument: A follow-up study. Financial Services Review 12 (3): 257-274.

Guiso, L., T. Jappelli, and D. Terlizzese. 1996. Income risk, borrowing constraints, and portfolio choice. The American Economic Review 86 (1): 158-172.

Hanna, S. D., W. Waller, and M. S. Finke. 2008. The concept of risk tolerance in personal financial planning. Journal of Personal Finance 7 (1): 96-108.

Hochguertel, S., R. Alessie, and A. van Soest. 1997. Saving accounts versus stocks and bonds in household portfolio allocation. The Scandinavian Journal of Economics 99 (1): 81-97. 
Hosmer Jr, D. W., S. Lemeshow, and R. X. Sturdivant. 2013. Applied Logistic Regression 398. John Wiley \& Sons.

Hunt, S. D., R. D. Sparkman Jr. and J. B. Wilcox. 1982. The pretest in survey research: Issues and preliminary findings. Journal of Marketing Research 19 (2): 269-273.

Huston, S. J. 2010. Measuring financial literacy. Journal of Consumer Affairs 44 (2): 296-316.

Jianakoplos, N. A., and A. Bernasek. 1998. Are women more risk averse? Economic inquiry 36 (4): 620-630.

Joo, S. H., and V. W. Pauwels. 2002. Factors Affecting Workers' Retirement Confidence: A Gender Perspective. Journal of Financial Counseling and Planning 13 (2).

Junarsin, E., and E. Tandelilin. 2008. Investment horizon to investment decision and mean reversion. Gadjah Mada International Journal of Business 10 (1): 77-112.

Kasten, G. W., and M. W. Kasten. 2011. The impact of aging on retirement income decision making. Journal of Financial Planning 24 (6).

Kimball, M. S. 1990. Precautionary saving in the small and in the large. Econometrica: Journal of the Econometric Society 53-73.

Lim, H., S. J. Heckman, C. P. Montalto, and J. Letkiewicz. 2014. Financial stress, self-efficacy, and financial help-seeking behavior of college students. Journal of Financial Counseling and Planning 25 (2): 148 160.

Lusardi, A. 1999. Information, expectations, and savings for retirement. Behavioral Dimensions of Retirement Economics 81: 115.

Lusardi, A. 2003. Planning and saving for retirement. Working paper. Dartmouth College.

Lusardi, A., and O. S. Mitchell. 2007b. Financial literacy and retirement preparedness: Evidence and implications for financial education. Business Economics 42 (1): 35-44.

Lusardi, A., and O. S. Mitchell. 2011. Financial literacy around the world: An overview. Journal of Pension Economics and Finance 10 (04): 497-508.

Markowitz, H. 1952. Portfolio selection. The Journal of Finance 7 (1): 77-91.

Merton, R. C. 2014. The crisis in retirement planning. Harvard Business Review 92 (7/8): 43-50.

Mitchell, O. S., and S. P. Utkus. 2003. Lessons from behavioral finance for retirement plan design. Philadelphia: Pension Research Council. The Wharton School, University of Pennsylvania.

Modigliani, F., and R. H. Brumberg. 1954. Utility analysis and the consumption function: An interpretation of cross-section data. Franco Modigliani 1: 388-436.

Munnell, A. H., J. P. Aubry, and L. Quinby. 2011. Public pension funding in practice. Journal of Pension Economics and Finance 10 (2): 247-268.

National Opinion Research Center. 1996. Survey of Consumer Finances. Chicago: Federal Reserve Board.

Pålsson, A. M. 1996. Does the degree of relative risk aversion vary with household characteristics? Journal of Economic Psychology 17 (6): 771-787.

Poterba, J. M. 2014. Retirement security in an aging population. American Economic Review 104 (5): 1-30.

Private Pension Administrator. 2014. About PRS. Private Retirement Scheme. Retrieved from http:// www.ppa.my/prs/about-prs/overview/ 
Sabri, M. F., and N. F. Zakaria. 2015. Financial well-being among young employees in Malaysia. In ZeynepCopur (Ed.), Handbook of Research on Behavioral Finance and Investment Strategies: Decision Making in the Financial Industry. Business Science Reference: 221.

Sapienza, P., L. Zingales, and D. Maestripieri. 2009. Gender differences in financial risk aversion and career choices are affected by testosterone. Proceedings of the National Academy of Sciences 106 (36): 15268-15273.

Schmeiser, M. D., and J. S. Seligman. 2013. Using the right yardstick: Assessing financial literacy measures by way of financial well being. Journal of Consumer Affairs 47 (2): 243-262.

Schooley, D. K., and D. Worden. 1996. Risk aversion measures: Comparing attitudes and asset allocation. Financial Services Review 5 (2): 87-99.

Sekita, S. 2011. Financial literacy and retirement planning in Japan. Journal of Pension Economics and Finance 10 (04): 637-656.

Shagar, L. K. 2016. Malaysians not saving enough for retirement. The Star Online (4 May). Retrieved from: http://www.thestar.com.my/news/nation/2016/05/04/malaysians-not-saving-enough-for-retirement/

Shum, P., and M. Faig. 2006. What explains household stock holdings? Journal of Banking \& Finance 30 (9): $2579-2597$.

Tan, H. K., and J. Y. Folk. 2011. Expected retirement age: A determinant of financial planning preparation in Malaysia. African Journal of Business Management 5 (22): 9370.

Tarrazo, M., and L. Gutierrez. 2000. Economic expectations, fuzzy sets and financial planning. European Journal of Operational Research 126 (1): 89-105.

TheFinancialBrand.com. 2013. When Marketing to Women, Financial Brands Fall Way Short (December 4). Retrieved from http://thefinancialbrand.com/35365/marketing-financial-services-banking-towomen/

US National Opinion Research Center. 1996. Survey of Consumer Finances. Chicago: Federal Reserve Board.

Van Rooij, M. C., A. Lusardi, and R. J. Alessie. 2011a. Financial literacy and retirement planning in the Netherlands. Journal of Economic Psychology 32 (4): 593-608.

Van Rooij, M., A. Lusardi, and R. Alessie. 2011b. Financial literacy and stock market participation. Journal of Financial Economics 101 (2): 449-472.

Van Rooij, M. C., A. Lusardi, and R. J. Alessie. 2012. Financial literacy, retirement planning and household wealth. Economic Journal 122 (560): 449-478.

Volpe, R. P., and H. Chen. 1998. An analysis of personal financial literacy among college students. Financial Services Review 7: 107-128.

Winchester, D. D., S. J. Huston, and M. S. Finke. 2011. Investor prudence and the role of financial advice. Journal of Financial Service Professionals 65 (4): 43-51.

Yakoboski, P., and J. Dickemper. 1997. Increased saving but little planning. results of the 1997 retirement confidence survey. EBRI Issue Brief 191: 1-21.

Yuh, Y., P. C. Montalto, and S. D. Hanna. 1998. Are Americans prepared for retirement? Financial Counseling and Planning 9 (1): 13. Retrieved from http://ssrn.com/abstract $=132568$

Yoong, J. 2011. Financial illiteracy and stock market participation: Evidence from the Rand American life panel. Financial Literacy: Implications for Retirement Security and the Financial Marketplace 76. 
